\title{
ANALISIS FAKTOR-FAKTOR YANG MEMPENGARUHI NILAI INFORMASI PELAPORAN KEUANGAN PEMERINTAH DAERAH PADA BPK-AD KANTOR WALIKOTA MANADO
}

\author{
Patras Thebora ${ }^{1}$, Jenny Morasa ${ }^{2}$, Sintje Rondonuwu ${ }^{3}$ \\ ${ }^{1,2,3}$ Fakultas Ekonomi dan Bisnis, Jurusan Akuntansi, Universitas Sam Ratulangi, \\ Jl. Kampus Bahu, Manado, 95115, Indonesia \\ E-mail : theborapatras65@gmail.com
}

\begin{abstract}
The objective of this research is to examine the factors that influence information value of local government financial reporting. Information value refers to reliability and timeliness. The factors that influence reliability and timeliness are human resource quality, information technology utilization, internal control system, and local financial monitoring.Local government financial management must be done according to the good governance, that are transparent and accountable, that allow users of financial statement to acces about theresult that local government accomplish. The objective of this research is to investigate the impact of human resources quality, utilization of information technology, local government financial controlling, and internal control system toward value of financial report information, which is timeliness. The research is talking place in BPK-AD of Mayor's Office, Manado. The research method used is quantitative, and the sample is all the population of the officer that works for the research object. The hypothesis test conclude that human resources quality, and utilization of information technology do not have significant impact, while local government financial control and internal control system do have significant effect towards timeliness of financial reporting in BPK-AD of Mayor's Office, Manado.

Keyword : Information value, Local Government Financial Report, Human resource quality, utilization of information technologies, local government financial control, and internal control system
\end{abstract}

\section{PENDAHULUAN}

Meningkatnya tuntutan masyarakat terhadap penyelenggaraan pemerintahan yang baik (good governance government), telah mendorong pemerintah pusat dan pemerintah daerah untuk menerapkan akuntabilitas publik. Dalam perkembangan sektor publik di Indonesia dewasa ini adalah menguatnya tuntunan akuntabilitas atas lembaga-lembaga publik. Akuntabilitas dalam arti luas merupakan kewajiban untuk memberikan pertanggungjawaban serta menerangkan kinerja dan tindakan seseorang, badan hokum atau pimpinan organisasi kepada pihak yang lain yang memiliki hak dank kewenangan untuk meminta pertanggungjawaban dan keterangan (Abdul 2012: 20). Sebagai salah satu bentuk pertanggungjawaban dalam penyelenggaraan pemerintahan yang diatur dalam Undang-Undang Nomor 17 Tahun 2003 tentang Keuangan Negara dan Undang-Undang Nomor 32 Tahun 2004 tentang Pemerintahan Daerah, upaya kongkrit untuk mewujudkan transparansi dan akuntabilitas pengelolaan keuangan pemerintah, baik pemerintah pusat maupun pemerintah daerah adalah dengan menyampaikan laporan pertanggungjawaban berupa laporan keuangan (Alifah, 2014).

Harus disadari bahwa ada banyak pihak yang akan mengandalkan informasi dalam laporan keuangan yang dipublikasikan oleh Badan Pengelola Keuangan dan Aset Daerah di Kantor Walikota Manado sebagai dasar untuk pengambilan keputusan. 
Oleh karena itu, informasi tersebut harus bermanfaat bagi para pemakai. Informasi yang terkandung di dalam laporan keuangan yang dihasilkan oleh pemerintah daerah harus sesuai dengan kriteria nilai informasi yang disyaratkan oleh peraturan perundang-undangan. Apabila tidak sesuai dengan perundang-undangan, maka akan menimbulkan permasalahan. Sebagai contoh, seperti dari hasil pemeriksaan pada tahun 2014, dinyatakan bahwa dalam 504 LKPD yang diperiksa, BPK hanya memberikan opini Wajar Tanpa Pengecualian (WTP) atas 251 LKPD dari 504 LKPD atau sebesar 49,80\%. Namun, capaian LKPD ini masih di bawah target RPJMN 2010-2014 yang telah menetapkan opini WTP atau seluruh LKPD pada tahun 2014 (IHPS, 2015: 69).

Hasil pemeriksaan atas 504 LKPD tahun 2014 mengungkapkan 5.978 permasalahan SPI. Permasalahan SPI tersebut meliputi 2.222 (37,17\%) kelemahan sistem pengendalian akuntansi dan pelaporan, 2.598 (43,46\%) kelemahan sistem pengendalian pelaksanaan anggaran pendapatan dan belanja, dan 1.158 (19,37\%) kelemahan struktur sistem pengendalian intern (IHPS, 2015: 76). Hasil pemeriksaan atas 504 LKPD tahun 2014 juga mengungkapkan 5.993 permasalahan ketidakpatuhan terhadap ketentuan peraturan perundang-undangan. Dari permasalahan ketidakpatuhan tersebut, sebanyak 3.638 permasalahan berdampak finansial yang meliputi 2.442 (40.41\%) kerugian daerah, $324(5,41 \%)$ potensi kerugian daerah, $892(14,88 \%)$ kekurangan penerimaan, dan 2.355 (39,30\%) kelemahan administrasi. (IHPS, 2015: 80).

Berdasarkan fenomena tersebut, dapat dinyatakan bahwa laporan keuangan yang dihasilkan oleh pemerintah daerah masih belum memenuhi kriteria nilai informasi yang disyaratkan, yaitu ketepat waktuan. Mengingat bahwa ketepat waktuan merupakan unsur penting dalam Laporan Keuangan Pemerintah Daerah sebagai dasar pengambilan keputusan, maka peneliti tertarik untuk meneliti faktor-faktor yang dapat mempengaruhi ketepatwaktuan pelaporan keuangan pemerintah daerah. Faktor-faktor tersebut yaitu kualitas sumber daya manusia, pemanfaatan teknologi informasi, pengawasan keuangan daerah dan sistem pengendalian intern terhadap nilai informasi pelaporan keuangan pemerintah daerah, yaitu ketepatwaktuan.

\section{TINJAUAN PUSTAKA}

\subsection{Akuntansi}

Ada terdapat bermacam-macam pengertian yang telah dikemukakan, tapi dari sekian pendapat yang ada kesemuanya intinya adalah sama. Adapun pendapat diantaranya sebagai berikut :

1. Akuntansi adalah proses identifikasi, pengumpulan, dan penyimpangan data serta proses pengembangan, pengukuran dan komunikasi (Marshall 2014: 11).

2. Akuntansi dapat didefinisikan dari dua sudut pandang yaitu definisi dari sudut pemakai jasa akuntansi dan dari sudut proses kegiatannya. Dari sudut pandang pemakai akuntansi dapat didefinisikan sebagai suatu disiplin ilmu yang menyediakan informasi berupa pelaporan keuangan yang diperlukan oleh pihak-pihak yang berkepentingan mengenai kegiatan ekonomi dan kondisi perusahaan (Pujiyanti, 2015: 19).

Dari definisi diatas dapat disimpulkan bahwa akuntansi adalah proses pengidentifikasian, pengukuran, dan pengkomunikasian informasi ekonomi sehingga memungkinkan adanya pertimbangan dan pengambilan keputusan berdasarkan informasi oleh para pengguna informasi tersebut. 


\subsection{Akuntansi Pemerintahan}

Menurut Peraturan Pemerintah Republik Indonesia Nomor 71 Tahun 2010 tentang SAP, akuntansi pemerintahan adalah proses identifikasi, pencatatan, pengukuran, pengklasifikasian, pengikhtisaran transaksi dan kejadian keuangan, penyajian laporan, serta penginterpretasian atas hasilnya. Akuntansi pemerintahan mengkhususnya dalam pencatatan dan pelaporan transaksi yang terjadi di badan pemerintah. Akuntansi pemerintahan menyediakan laporan akuntansi tentang aspek kepengurusan dari administrasi keuangan negara (Deddy, dkk 2014: 4).

\subsection{Akuntabilitas dan Transparansi}

Akuntabilitas merupakan pertanggungjawaban dengan menciptakan pengawasan melalui distribusi kekuasaan pada berbagai lembaga pemerintah sehingga mengurangi penumpukan kekuasaan sekaligus menciptakan kondisi saling mengawasi (check and balances system). Akuntabilitas dalam instansi pemerintah adalah kewajiban untuk memberikan pertanggungjawaban atau menjawab dan menerangkan kinerja dan tindakan seseorang atau badan hukum atau pimpinan suatu organisasi kepada pihak yang memiliki hak atau berkewenangan untuk meminta keterangan atau pertanggungjawaban (Abdul, 2012: 83).

Yang dimaksud dengan transparansi yaitu informasi keuangan daerah harus mampu menyajikan dan menyediakan informasi yang terbuka serta mudah diakses dan dipahami oleh semua pihak sesuai peraturan perundangan yang berlaku. Sedangkan akuntabel yaitu pengelolaan keuangan daerah yang tercermin dalam laporan keuangan yang dihasilkan dapat dipertanggungjawabkan. Menurut Annisa, $d k k$ (2014), transparansi diperlukan agar demikian masyarakat umum dan komunitas bisnis dapat mengawasi pelaksanaan negara secara obyektif. Apalagi prinsip dasar pertanggungjawaban berisi unsur penjelasan di dalam fungsi organisasi dan bagaimana mengatasinya mereka. Untuk itu, setiap pejabat negara harus melakukannya menjalankan tugasnya dengan jujur dan terukur sesuai dengan hukum dan peraturan dan untuk menghindari penyalahgunaan kekuasaan Salah satu kepala sekolah pedoman pelaksanaan akuntabilitas adalah laporan pertanggungjawaban diserahkan secara teratur sesuai dengan peraturan.

\subsection{Nilai Informasi}

Agar manfaat dan tujuan penyajian laporan keuangan pemerintah dapat dipenuhi maka informasi yang disajikan harus merupakan informasi yang bermanfaat bagi pihak yang berkepentingan dengan informasi tersebut. Menurut Sinarwati (2015) pemakai akan mempercayai laporan keuangan jika informasi tersebut dipahami, tidak menyesatkan dan bermanfaat bagi pemakai. Karakteristik kualitatif laporan keuangan adalah ukuran-ukuran normatif yang perlu diwujudkan dalam informasi akuntansi sehingga dapat memenuhi tujuannya. Adapun karakteristik kualitatif laporan keuangan pemerintah antara lain (Peraturan Pemerintah Nomor 24 Tahun 2005) :

1. Relevan,

- Manfaat umpan balik (feedback value),

- Manfaat prediktif (predictive value),

- Tepat waktu (timeliness) dan

- Lengkap.

2. Andal,

- Penyajian jujur,

- Dapat diverifikasi (verifiability) dan,

- Netralitas. 


\section{Dapat dibandingkan dan, \\ 4. Dapat dipahami.}

\subsection{Kualitas Sumber Daya Manusia}

Menurut Sembiring (2013), kualitas sumber daya manusia adalah kemampuan sumber daya manusia untuk melaksanakan tugas dan tanggung jawab yang diberikan kepadanya dengan bekal pendidikan, pelatihan, dan pengalaman yang cukup memadai. Dengan latar belakang pendidikan yang sesuai dengan kerjanya, seseorang akan lebih mudah memahami dan melaksanakan tugasnya. Ditambah dengan pelatihan yang diberikan dari instansi, maka membuat seseorang dari yang tidak bisa menjadi bisa dan yang sudah baik menjadi lebih baik. Selain itu, penguasaan teknologi dan kesehatan yang baik pun bisa menunjang kinerja. Dengan demikian semakin baik kualitas sumber daya manusia, semakin baik pula kinerja pemerintah daerah.

\subsection{Pemanfaatan Teknologi Informasi}

Pemanfaatan teknologi informasi adalah perilaku atau sikap seseorang menggunakan teknologi informasi untuk menyelesaikan tugas dan meningkatkan kinerjanya. Secara umum pemanfaatan teknologi akan memberikan dampak positif karena memberikan kemudahan dan efisiensi waktu dan biaya. Jadi jika teknologi informasi dimanfaatkan secara optimal dan memberikan pengaruh positif terhadap kinerja pemerintah daerah. (Argo, 2015).

\subsection{Pengawasan Keuangan Daerah}

Pengawasan menurut peraturan Pemerintah Nomor 76 Tahun 2005 tentang pedoman dan pembinaan pengawasan penyelenggaraan pemerintah daerah. Pasal 1 (satu) menyebutkan, bahwa pengawasan pemerintah adalah proses kegiatan yang ditunjukan untuk menjamin agar pemerintah daerah berjalan sesuai dengan rencana dan ketentuan peraturan perundang-undangan yang berlaku. Menurut Husna (2013) yang dimaksud dengan pengawasan adalah suatu upaya yang sistematik untuk menetapkan kinerja standar pada perencanaan untuk membandingkan kinerja aktual dengan standar yang telah ditentukan, untuk menetapkan apakah telah terjadi penyimpangan, serta untuk mengambil tindakan perbaikan yang diperlukan untuk menjamin bahwa sumber data organisasi atau pemerintahan telah digunakan seefektif dan seefisien mungkin guna mencapai tujuan organisasi atau pemerintahan.

\subsection{Sistem Pengendalian Intern (SPI)}

Menurut Astuti, $d k k$ (2014) Sistem Pengendalian Intern (SPI) meliputi lima unsur pengendalian yaitu: lingkungan pengendalian, penilaian risiko, kegiatan pengendalian, informasi dan komunikasi, serta pemantauan SPI dinyatakan efektif apabila mampu memberikan keyakinan memadai atas tercapainya. Pengendalian intern didefinisikan sebagai suatu proses yang dipengaruhi oleh sumber daya manusia dan sistem teknologi informasi yang dirancang untuk membantu organisasi mencapai suatu tujuan tertentu. Pengendalian intern merupakan suatu cara untuk mengarahkan, mengawasi, dan mengukur sumber daya suatu organisasi, serta berperan penting dalam pencegahan dan pendeteksian penggelapan (fraud). Pengendalian intern terdiri atas kebijakan dan prosedur yang digunakan dalam mencapai sasaran dan menjamin atau menyediakan informasi keuangan yang andal, serta menjamin ditaatinya hukum dan peraturan yang berlaku. 


\subsection{Ketepatwaktuan (Timeliness) Pelaporan Keuangan}

Ketepatwaktuan (timeliness) merupakan salah satu faktor penting dalam menyajikan suatu informasi yang relevan. Karakteristik informasi yang relevan harus mempunyai nilai prediktif dan dapat disajikan tepat waktu. Laporan keuangan sebagai sebuah informasi akan bermanfaat apabila informasi yang dikandungnya disediakan tepat waktu bagi pembuat keputusan sebelum informasi tersebut kehilangan kemampuannya dala mempengaruhi pengambilan keputusan. Jika terdapat penundaan yang tidak semestinya dalam pelaporan, maka informasi yang dihasilkan akan kehilangan relevansinya (Zuliarti, 2012).

Menurut Triasaputra (2013) ketepatwaktuan pelaporan keuangan bukan hanya dibutuhkan oleh organisasi sektor publik saja, tetapi organisasi non sektor publik juga membutuhkan hal yang sama yaitu ketepatwaktuan pelaporan keuangan. Ketepatwaktuan menunjukan bahwa laporan keuangan harus disajikan pada kurun waktu yang teratur untuk memperlihatkan perubahan keadaan perusahaan yang pada gilirannya mungkin akan mempengaruhi prediksi dan keputusan pemakai. Sehingga dapat mendukung manajer menghadapi ketidakpastian yang terjadi dalam lingkungan kerja mereka. Informasi yang tepat waktu dipengaruhi kemampuan manajer dalam merespon setiap kejadian atau permasalahan.

\subsection{Pelaporan Keuangan Pemerintah}

Pada dasarnya, laporan keuangan merupakan bentuk pertanggungjawaban pengelolaan sumber daya ekonomi yang dimiliki oleh entitas. Laporan yang dipublikasikan disusun berdasarkan standar akuntansi sehingga laporan keuangan dapat terjawab dibandingkan dengan laporan keuangan periode sebelumnya atau dapat dibandingkan dengan laporan keuangan PT Entitas lainnya Laporan keuangan merupakan produk akhir dari proses akuntansi (Suwanda, 2015).

Laporan keuangan pemerintah merupakan komponen penting dalam mewujudkan akuntabilitas pengelolaan keuangan kepada publik. Adanya tuntutan yang semakin besar terhadap pelaksanaan akuntabilitas publik menimbulkan implikasi bagi manajemen di instansi pemerintah untuk memberikan informasi kepada publik, salah satunya adalah informasi dalam laporan keuangan (Pituringsih,2015).

\section{METODE PENELITIAN}

\subsection{Jenis Penelitian}

Dalam penelitian ini menggunakan metode kuantitatif dimana penelitian ini bertujuan untuk menganalisis apakah kualitas sumber daya manusia, pemanfaatan teknologi informasi, pengawasan keuangan daerah dan sistem pengendalian intern berpengaruh terhadap nilai informasi pelaporan keuangan pemerintah daerah.

\subsubsection{Jenis Data}

Dalam melakukan analisis dan pembahasan terhadap masalah dalam penelitian ini menggunakan data kuantitatif berupa jawaban responden dalam bentuk kuesioner yang diukur dengan skala.

\subsubsection{Sumber Data}

Data diperoleh dari BPK-AD kantor Walikota Manado. Jenis data yang digunakan dalam penelitian ini merupakan data primer dan data sekunder. Data tersebut berupa kuesioner yang akan diisi atau dijawab oleh responden yang terkait dengan faktor-faktor yang mempengaruhi nilai informasi pelaporan keuangan pemerintah daerah pada BPK-AD Kantor Wailkota Manado. 


\subsection{Tempat dan Waktu Penelitian}

Tempat penelitian yang akan dipilih oleh peneliti adalah Pemerintah Kota Manado, yaitu BPK-AD (Badan Pengelola Keuangan dan Aset Daerah) Kantor Walikota Manado yang beralamat di Jalan B.W. Lapian Tikala Kota Manado. Waktu Penelitian adalah dimulai dari bulan Juni 2017 sampai dengan selesai.

\subsection{Prosedur Penelitian}

1. Interview

Teknik pengumpulan data dengan cara mengadakan wawancara langsung dengan pihak perusahaan mengenai data yang berhubungan dengan masalah yang dibahas.

2. Observasi

Teknik pengumpulan data dengan cara terjun langsung ke objek yang diteliti dan mengamati apa yang menjadi sasaran bahan pengambilan data yang sesuai dengan apa yang diperlukan.

3. Kuesioner

Teknik pengumpulan data dengan cara menyususn daftar pertanyaan yang akan dijawab oleh pihak perusahaan dan industri mengenai data yang berhubungan dengan masalah yang dibahas.

\subsection{Populasi dan Sampel}

Populasi adalah kelompok elemen yang lengkap, yang biasanya berupa orang, objek, transaksi, atau kejadian dimana kita tertarik untuk mempelajarinya atau menjadi objek penelitian. Populasi dalam penelitian ini adalah Pegawai BPK-AD Kantor Walikota Manado. Sedangkan sampel adalah suatu himpunan bagian dari unit populasi. (Koncuru, 2013: 118).

Penyempelan atas responden dilakukan secara purposive. Adapun kriteria responden dalam penelitian ini adalah para pegawai yang dibagian $\mathrm{BPK}-\mathrm{AD}$, yang meliputi pegawai sub bagian akuntansi/penatausahaan keuangan. Jumlah kuesioner yang dikirim kepada responden sebanyak 30 kuesioner, yang didistribusikan langsung oleh peneliti kepada responden

\subsection{Metode Pengumpulan Data}

Untuk melakukan penelitian ini dilakukan suatu teknik atau metode melalui data tertulis dan data tidak tertulis yang diperoleh dengan cara penelitian lapangan yang merupakan langkah pengumpulan data dengan melakukan tinjauan langsung ke objek penelitian, dengan mengajukan surat permohonan kepada pihak terkait untuk dapat membantu selama proses penelitian untuk kepentingan penyusunan skripsi dengan memberikan data-data yang dibutuhkan. Selain itu pengumpulan data juga dilakukan melalui wawancara dengan melakukan tanya jawab dengan pihak-pihak yang berwenang dan juga dilakukan melalui penyebaran kuesioner kepada kepala bagian dan staf sehubungan dengan data dan informasi yang diperlukan dalam penelitian.

\subsection{Metode Analisis}

\subsubsection{Uji Validitas dan Reliabilitas}

Validitas kriteria diukur dengan cara menghitung korelasi antara skor masing masing butir dengan skor total menggunakan teknik korelasi person. Bilamana koefisien korelasi positif dan $\geq 0,3$ maka indikator yang bersangkutan dianggap valid (Wibowo, 2012: 20). 
Menurut Wibowo (2012: 20), salah satu pengukuran reliabilitas adalah menggunkan koefisien cronbach alpha, dimana jika nilai Alpha > 0,6 menunjukan instrument tersebut reliabel.

\subsubsection{Pengujian Asumsi Klasik}

\section{Uji Normalitas}

Dalam penelitian ini uji normalitas dilakukan dengan uji statistik yaitu one sample Kolmogorov smirniw test. Uji normalitas ini akan menguji data variabel bebas dan data variabel terikat pada persamaan regresi yang dihasilkan, apakah berdistribusi normal atau berdistribusi tidak normal. Uji ini dilakukan untuk menunjukan simetris tidaknya distribusi data. Dasar pengambilan keputusan dalam uji normalitas yakni, jika nilai signifikansi lebih besar dari 0,05 maka data tersebut berdistribusi normal. Sebaliknya jika nilai signifikan lebih kecil dari 0.05 maka data tersebut tidak berdistribusi normal.

\section{Uji Multikolinieritas}

Uji multikolinieritas bertujuan untuk menguji apakah model regresi ditemukan adanya korelasi antar variabel bebas (independen variable). Model regresi yang baik seharusnya tidak terjadi korelasi di antara variabel independen. Jika variabel independen saling berkorelasi, maka variabel ini tidak orthogonal. Variabel orthogonal adalah variabel independen yang nilai korelasi antar sesama variabel independen sama dengan nol. Suatu model regresi dinyatakan bebas dari multikolinearitas jika mempunyai niali VIF $<10.00$ dan mempunyai tolerance diatas 0,10 dengan model regresi.

\section{Uji Heteroskedastisitas}

Uji heteroskedastisitasbertujuan bertujuan menguji apakah dalam model regresi terjadi ketidaksamaan variance dari residual satu pengamatan ke pengamatan yang lain. Jika variance dari residual satu pengamatan ke pengamatan lain tetap, maka disebut homoskedastisitas. Model regrasi yang baik adalah yang homoskedastisitas atau tidak terjadi heteroskedastisitas. Metode uji heteroskedastisitas ini menggunakan Uji Koefisien Korelasi Spearman's rho yaitu dimana mengkorelasikan variavel independen dengan nilai unstandardized residual. Jika korelasi antara variabel independen dengan residual di dapat signifikansi lebih dari 0,05 maka dapat dikatakan bahwa tidak terjadi masalah heteroskedastisitas pada model regresi.

\subsubsection{Pengujian Hipotesis}

\section{Uji-t (uji parsial)}

Uji parsial atau uji t bertujuan untuk menguji apakah variabel bebas berpengaruh secara individu terhadap variabel terikatnya. Bentuk pengujianya adalah sebagai berikut :

Ho1 : $\beta=0$ (kualitas sumber daya manusia tidak berpengaruh terhadap ketepatwaktuan)

Ha1 : $\beta \neq 0$ (kualitas sumber daya manusia berpengaruh terhadap ketepatwaktuan)

Ho2 : $\beta=0$ (pemanfaatan teknologi informasi tidak berpengaruh terhadap ketepatwaktuan)

Ha2 : $\beta \neq 0$ (pemanfaatan teknologi informasi berpengaruh terhadap ketepatwaktuan)

Ho3 : $\beta=0$ (pengawasan keuangan daerah tidak berpengaruh terhadap ketepatwaktuan)

Ha3 : $\beta \neq 0$ (pengawasn keuangan daerah berpengaruh terhadap ketepatwaktuan)

Ho4 : $\beta=0$ (sistem pengendalian intern tidak berpengaruh terhadap ketepatwaktuan)

Ha4 : $\beta \neq 0$ (sistem pengendalian intern berpengaruh terhadap ketepatwaktuan) 
Selanjutnya akan dilakukian uji signifikansi dengan membandingkan tingkat signifikansi (alpha) $\alpha=5 \%$ dan derajat kebebasan (n-k) dengan $t_{\text {hitung }}$ yang diperoleh dengan kriteria uji yang digunakan adalah :

$\mathrm{H}_{0}$ ditolak apabila $\mathrm{t}_{\text {hitung }}>\mathrm{t}_{\text {tabel }}$

$\mathrm{H}_{\mathrm{a}}$ diterima apabila $\mathrm{t}_{\text {hitung }}<\mathrm{t}_{\text {tabel }}$

Maka kriteria penerimaan atau penolakan hipotesis yaitu sebagai berikut :

1. Jika $t_{\text {hitung }} \leq \mathrm{t}_{\text {tabel }}$ maka $\mathrm{H}_{0}$ ada didaerah penolakan, berarti $\mathrm{H}_{\mathrm{a}}$ diterima artinya antara variabel $\mathrm{X}$ dan $\mathrm{Y}$ ada hubungannya.

2. Jika $t_{\text {hitung }} \geq t_{\text {tabel }}$ maka $H_{0}$ ada didaerah penerimaan, berarti $H_{a}$ ditolak artinya variabel $\mathrm{X}$ dan $\mathrm{Y}$ tidak ada hubungan.

\section{Uji F}

Menurut Ramadhanti (2016), test F digunakan untuk mengetahui apakah ada pengaruh simultan independen variabel pada variabel dependen. Bukti dilakukan dengan membandingkan nilai $\mathrm{F}_{\text {hitung }}$ dengan $\mathrm{F}_{\text {tabel }}$ pada tingkat signifikansi $5 \%$. Kriteria uji yang digunakan adalah:

Jika $F_{\text {hitung }}>F_{\text {tabel }}(n-k-1)$ maka Ho ditolak

Arti dari data statistik yang digunakan untuk membuktikan bahwa semua variabel independen memiliki berpengaruh pada nilai variabel.

Jika $F_{\text {hitung }}<\mathrm{F}_{\text {tabel }}(\mathrm{n}-\mathrm{k}-1)$ maka Ho diterima

Arti dari data statistik yang digunakan untuk membuktikan bahwa semua variabel independen tidak memiliki berpengaruh pada nilai variabel.

\section{Koefisien Determinasi}

Koefisien korelasi $\left(\mathrm{R}^{2}\right)$ berganda adalah indeks atau angka yang digunakan untuk mengukur keeratan hubungan antara dua variabel bebas atau lebih dengan satu variabel terikat. Nilai $R$ dapat divariasi dari -1 sampai dengan +1 (positif satu) dimana :

1. Jika nilai $\mathrm{R}=0$ (nol) atau mendekati nol maka hubungan antara kedua variabel adalah sempurna positif atau kuat sekali.

2. Jika $\mathrm{R}=+1$ (positif satu) atau mendekati satu maka hubungan antara kedua variabel adalah sempurna positif atau kuat sekali.

3. Bila $\mathrm{R}=-1$ (negative satu ) atau mendekati negative satu maka hubungan antara kedua variabel adalah sempurna negative atau kuat sekali.

Koefisien Determinasi $\left(\mathrm{R}^{2}\right)$ digunakan sebagai patokan untuk menunjukkan seberapa besar variabel mampu menjelaskan variabel terkait dan mengetahui kelayakan model analisis yang digunakan untuk penelitian di masa yang akan datang. Koefisien determinasi $\left(\mathrm{R}^{2}\right)$ dunyatakan dalam presentase yang nilainya berkisar antara 0 dan 1 . Semakin besar nilai $\mathrm{R}^{2}$, maka semakin kuat hubungan kedua variabel. Jika $\mathrm{R}^{2}=0$ maka tidak ada korelasi dan jika $\mathrm{R}^{2}=1$ maka ada korelasi sempurna.

\subsection{Variabel Penelitian}

\subsubsection{Variabel Independen $(X)$}

Variabel independen yaitu variabel yang mempengaruhi variabel lain yang tidak bebas. Dalam hubungannya dengan judul yang ditetapkan, menjadi variabel independen adalah kualitas sumber daya manusia, pemanfaatan teknologi informasi, pengawasan keuangan daerah dan sistem pengendalian intern.

\subsubsection{Variabel Dependen (Y)}

Variabel dependen yaitu variabel yang dipengaruhi oleh variabel lainnya, maka yang menjadi variabel dependen dalam penelitian ini adalah ketepat waktuan pelaporan keuangan pemerintah daerah. 


\subsection{Definisi Operasional}

\subsubsection{Kualitas sumber daya manusia (X1)}

Kualitas sumber daya manusia yang merupakan variabel independen dalam penelitian ini adalah kemampuan dari staf bagian akuntansi/keuangan dalam melaksanakan tugasnya berdasarkan latar belakang pendidikan, pelatihan yang diperoleh responden, pemahaman mengenai tugas, dan tanggung jawab terhadap kewajiban. Pengukuran variabel ini menggunakan instrumen kuesioner, dengan model skala Likert lima poin. Responden diminta untuk menyatakan setuju atau ketidaksetujuannya terhadap pertanyaan yang diajukan sesuai dengan kondisi yang sesungguhnya.

\subsubsection{Pemanfaatan Teknologi Informasi (X2)}

Pemanfaatan teknologi informasi merupakan penggunaan secara optimal dari perangkat keras (hardware), perangkat lunak (software), jaringan (internet), dan jenis lainnya yang berhubungan dengan teknologi. Pemanfaatan teknologi informasi mencakup adanya pengolahan data, pengolahan informasi, system manajemen dan proses kerja secara elektronik dan pemanfaatan kemajuan teknologi informasi agar pelayanan publik dapat diakses secara mudah dan murah oleh masyarakat (Argo, 2015). Pengukuran variabel ini menggunakan instrumen kuesioner, dengan model skala likert lima poin. Responden diminta untuk menyatakan setuju atau ketidaksetujuannya terhadap pertanyaan yang diajukan sesuai dengan kondisi yang sesungguhnya.

\subsubsection{Pengawasan Keuangan Daerah (X3)}

Pengawasan keuangan daerah merupakan proses kegiatan yang ditujukan untuk menjamin agar pemerintahan daerah berjalan secara efektif dan efisien sesuai dengan rencana dan ketentuan peraturan perundang-undangan (Peraturan Menteri Dalam Negeri Nomor 51 Tahun 2010). Pengawasan pada dasarnya diarahkan sepenuhnya untuk menghindari adanya kemungkinan penyelewengan atau penyimpangan atas tujuan yang akan dicapai. Pengawasan dapat membantu penyelenggaraan pemerintah melaksanakan kebijakan yang telah ditetapkan untuk mencapai tujuan yang telah direncanakan secara efektif dan efisien. Pengawasan pada dasarnya mencakup empat unsur yang terdari dari penetapan standar pelaksanaan tujuan organisasi, pengukuran pelaksanaan tujuan organisasi yang nyata \& membandingkannya dengan standar yang telah ditetapkan, dan pengambilan tindakan koreksi yang diperlukan bila pelaksanaan menyimpang dari standar yang berlaku. Pengukuran variabel ini menggunakan instrumen kuesioner, dengan model skala Likert lima poin. Responden diminta untuk menyatakan setuju atau ketidaksetujuannya terhadap pertanyaan yang diajukan sesuai dengan kondisi yang sesungguhnya.

\subsubsection{Sistem Pengendalian Intern (X4)}

Sistem Pengendalian Intern (SPI) merupakan suatu cara untuk mengarahkan, mengawasi, dan mengukur sumber daya suatu organisasi, serta berperan penting dalam pencegahan dan pendeteksian penggelapan (fraud). Pengendalian intern terdiri atas kebijakan dan prosedur yang digunakan dalam mencapai sasaran dan menjamin atau menyediakan informasi keuangan yang andal, serta menjamin ditaatinya hukum dan peraturan yang berlaku. Pengukuran variabel ini menggunakan instrumen kuesioner, dengan model skala likert lima poin. Responden diminta untuk menyatakan setuju atau ketidaksetujuannya terhadap pertanyaan yang diajukan sesuai dengan kondisi yang sesungguhnya. 


\subsubsection{Ketepatwaktuan Pelaporan Keuangan (Y)}

Ketepatwaktuan adalah tersedianya informasi bagi pembuat keputusan pada saat dibutuhkan sebelum informasi tersebut kehilangan kekuatan untuk mempengaruhi keputusan (Peraturan Pemerintah Nomor 24 Tahun 2005). Berikut kriteria penilaian dalam kuesioner, yaitu :

1. Sangat Tidak Setuju, mempunyai skor 1 ,

2. Tidak Setuju, mempunyai skor 2,

3. Netral, mempunyai skor 3 ,

4. Setuju, mempunyai skor 4, dan

5. Sangat Setuju, mempunyai skor 5.

Responden diminta untuk menyatakan setuju atau ketidaksetujuannya terhadap pertanyaan yang diajukan sesuai dengan kondisi yang sesungguhnya.

\section{HASIL ANALISIS DAN PEMBAHASAN}

\subsection{Hasil Penelitian}

\subsubsection{Deskriptif Data Responden}

1. Jenis Kelamin

\begin{tabular}{|l|l|l|}
\hline Jenis Kelamin & Frekuensi & Presentase \\
\hline Pria & 13 & $43 \%$ \\
\hline Wanita & 17 & $57 \%$ \\
\hline TOTAL & 30 & $100 \%$ \\
\hline
\end{tabular}

Berdasarkan tabel di atas diketahui bahwa responden sebagian besar berjenis kelamin Wanita sebesar 57\%. Sehingga dapat disimpulkan bahwa sebagian besar badan pengelola keuangan dan aset daerah kantor walikota manado adalah berjenis kelamin Wanita.

\section{Latar Belakang Pendidikan}

\begin{tabular}{|l|c|r|}
\hline Pendidikan & Frekuensi & Presentase \\
\hline SLTA & 10 & $33 \%$ \\
\hline DIPLOMA & 6 & $17 \%$ \\
\hline S1 & 13 & $47 \%$ \\
\hline S2 & 1 & $3 \%$ \\
\hline TOTAL & 30 & $100 \%$ \\
\hline
\end{tabular}

Berdasarkan tabel di atas diketahui bahwa responden sebagian besar berpendidikan S1. Hal ini diketahui dari persentasenya sebesar $47 \%$.

\section{Jabatan}

\begin{tabular}{|l|c|c|}
\hline Jabatan & Frejuensi & Presentase \\
\hline Staf & 15 & $50 \%$ \\
\hline Penata Laporan Keuangan & 14 & $47 \%$ \\
\hline Kasubid. Monev Keuangan & 1 & $3 \%$ \\
\hline TOTAL & 30 & $100 \%$ \\
\hline
\end{tabular}

Berdasarkan tabel di atas diketahui bahwa di BPK-AD Kota Manado jumlah jabatan paling besar adalah staf. Hal ini diketahui dari persentasenya sebesar $50 \%$. 


\section{Pelatihan}

\begin{tabular}{|l|c|r|}
\hline Pelatihan & Frekuensi & Presentase \\
\hline Prajabatan & 11 & $37 \%$ \\
\hline Bimtek Pengelolaan Keuangan & 5 & $17 \%$ \\
\hline TOT. Keuangan Daerah Tahun 2015 & 4 & $13 \%$ \\
\hline TOTAL & 20 & $67 \%$ \\
\hline
\end{tabular}

Berdasarkan tabel di atas diketahui bahwa pelatihan yang paling banyak diikuti oleh responden adalah Prajabatan. Hal ini diketahui dari persentasenya sebesar $37 \%$.

\subsubsection{Uji Validitas}

\begin{tabular}{|c|c|c|c|}
\hline Item Pertanyaan & r hitung & $r$ tabel & Keterangan \\
\hline KSDM1 & 0,619 & 0,361 & Valid \\
\hline KSDM2 & 0,430 & 0,361 & Valid \\
\hline KSDM3 & 0.682 & 0,361 & Valid \\
\hline KSDM4 & 0,514 & 0,361 & Valid \\
\hline KSDM5 & 0,568 & 0,361 & Valid \\
\hline KSDM6 & 0,545 & 0,361 & Valid \\
\hline KSDM7 & 0,508 & 0,361 & Valid \\
\hline KSDM8 & 0,564 & 0,361 & Valid \\
\hline PTI1 & 0,637 & 0,361 & Valid \\
\hline PTI2 & 0,661 & 0,361 & Valid \\
\hline PTI3 & 0,704 & 0,361 & Valid \\
\hline PTI4 & 0,602 & 0,361 & Valid \\
\hline PTI5 & 0,567 & 0,361 & Valid \\
\hline PTI6 & 0,704 & 0,361 & Valid \\
\hline PTI7 & 0,531 & 0,361 & Valid \\
\hline PTI8 & 0,608 & 0,361 & Valid \\
\hline PTI9 & 0,378 & 0,361 & Valid \\
\hline PTI10 & 0,520 & 0,361 & Valid \\
\hline PKD1 & 0,669 & 0,361 & Valid \\
\hline PKD2 & 0,861 & 0,361 & Valid \\
\hline PKD3 & 0,844 & 0,361 & Valid \\
\hline PKD4 & 0,442 & 0,361 & Valid \\
\hline PKD5 & 0,559 & 0,361 & Valid \\
\hline SPI1 & 0,680 & 0,361 & Valid \\
\hline SPI2 & 0,497 & 0,361 & Valid \\
\hline SPI3 & 0,556 & 0,361 & Valid \\
\hline SPI4 & 0,637 & 0,361 & Valid \\
\hline SPI5 & 0,716 & 0,361 & Valid \\
\hline KT1 & 0,818 & 0,361 & Valid \\
\hline KT2 & 0,654 & 0,361 & Valid \\
\hline KT3 & 0,474 & 0,361 & Valid \\
\hline KT4 & 0,683 & 0,361 & Valid \\
\hline
\end{tabular}

Berdasarkan dari tabel diatas diketahui bahwa masing-masing item yang menyusun masing-masing koesioner memiliki $\mathrm{r}$ hitung lebih dari $\mathrm{r}$ tabel ( $\mathrm{r}$ hitung $>0,361$ ), yang berarti masing-masing item dari variabel kualitas sumber daya manusia, pemanfaatan teknologi informasi, sistem pengendalian intern, dan 
ketepatwaktuan pelaporan keuangan adalah valid. Dengan demikian syarat validitas dari alat ukur terpenuhi.

\subsubsection{Uji Reliabilitas}

\section{Kualitas Sumber Daya Manusia}

\begin{tabular}{|r|r|}
\hline $\begin{array}{c}\text { Cronbach's } \\
\text { Alpha }\end{array}$ & $\begin{array}{c}\text { N of } \\
\text { Items }\end{array}$ \\
\hline .726 & 9 \\
\hline
\end{tabular}

Dari nilai reliabilitas kualitas sumber daya manusia Cronbach's Alpha sebesar 0,726 dan dinyatakan reliabel karena nilainya lebih besar dari 0,60 $(0,726 \geq 0,60)$.

\section{Pemanfaatan Teknologi Informasi}

\begin{tabular}{|r|r|}
\hline $\begin{array}{c}\text { Cronbach's } \\
\text { Alpha }\end{array}$ & $\begin{array}{c}\text { N of } \\
\text { Items }\end{array}$ \\
\hline .748 & 11 \\
\hline
\end{tabular}

Dari nilai reliabilitas pemanfaatan teknologi informasi Cronbach's Alpha sebesar 0,748 dan dinyatakan reliabel karena nilainya lebih besar dari 0,60 $(0,748 \geq 0,60)$.

\section{Sistem Pengendalian Intern}

\begin{tabular}{|r|r|}
\hline $\begin{array}{c}\text { Cronbach's } \\
\text { Alpha }\end{array}$ & $\begin{array}{c}\mathrm{N} \text { of } \\
\text { Items }\end{array}$ \\
\hline .736 & 6 \\
\hline
\end{tabular}

Dari nilai reliabilitas pemanfaatan teknologi informasi Cronbach's Alpha sebesar 0,736 dan dinyatakan reliabel karena nilainya lebih besar dari 0,60 $(0,736 \geq 0,60)$.

\section{Pengawasan Keuangan Daerah}

\begin{tabular}{|r|r|}
\hline $\begin{array}{c}\text { Cronbach's } \\
\text { Alpha }\end{array}$ & $\begin{array}{c}\text { N of } \\
\text { Items }\end{array}$ \\
\hline .773 & 6 \\
\hline
\end{tabular}

Dari nilai reliabilitas pemanfaatan teknologi informasi Cronbach's Alpha sebesar 0,773 dan dinyatakan reliabel karena nilainya lebih besar dari 0,60 $(0,773 \geq 0,60)$.

\section{Ketepatwaktuan Pelaporan Keuangan}

\begin{tabular}{|r|c|}
\hline $\begin{array}{c}\text { Cronbach's } \\
\text { Alpha }\end{array}$ & $\begin{array}{c}\text { N of } \\
\text { Items }\end{array}$ \\
\hline .727 & 5 \\
\hline
\end{tabular}

Dari nilai reliabilitas pemanfaatan teknologi informasi Cronbach's Alpha sebesar 0,727 dan dinyatakan reliabel karena nilainya lebih besar dari 0,60 $(0,727 \geq 0,60)$. 


\subsubsection{Asumsi Klasik}

\section{Uji Normalitas}

\begin{tabular}{|cc|r|}
\hline & & $\begin{array}{r}\text { Unstandardiz } \\
\text { ed Residual }\end{array}$ \\
\hline & $\mathrm{N}$ & 30 \\
& Mean & .0000000 \\
Normal Parameters ${ }^{\mathrm{a}, \mathrm{b}}$ & Std. & .74470924 \\
& Deviation & \\
Most Extreme & Absolute & .154 \\
Differences & Positive & .073 \\
& Negative & -.154 \\
Kolmogorov-Smirnov Z & .844 \\
Asymp. Sig. (2-tailed) & .475 \\
\hline
\end{tabular}

Berdasarkan nilai signifikansi dengan menggunakan uji One Sample Kolmogorof-Smirnov Test sebesar 0,475 lebih besar dari 0,05. Sehingga dapat disimpulkan data residual berdistribusi normal.

2. Uji Multikolinearitas

\begin{tabular}{|c|c|c|c|c|c|c|c|}
\hline \multirow[b]{2}{*}{ Model } & \multicolumn{2}{|c|}{$\begin{array}{c}\text { Unstandardized } \\
\text { Coefficients }\end{array}$} & \multirow{2}{*}{$\begin{array}{c}\text { Standardize } \\
\mathrm{d} \\
\text { Coefficient } \\
\mathrm{s} \\
\text { Beta }\end{array}$} & \multirow[t]{2}{*}{$\mathrm{T}$} & \multirow[t]{2}{*}{ Sig. } & \multicolumn{2}{|c|}{$\begin{array}{l}\text { Collinearity } \\
\text { Statistics }\end{array}$} \\
\hline & B & $\begin{array}{l}\text { Std. } \\
\text { Error }\end{array}$ & & & & $\begin{array}{c}\text { Toleran } \\
\text { ce }\end{array}$ & VIF \\
\hline $\begin{array}{c}\text { (Constan } \\
\text { t) }\end{array}$ & -4.590 & 4.899 & & -.937 & .358 & & \\
\hline $\mathrm{X} 1$ & .156 & .100 & .232 & 1.554 & .133 & .882 & 1.133 \\
\hline $\mathrm{X} 2$ & .134 & .070 & .302 & 1.930 & .065 & .802 & 1.247 \\
\hline X3 & .243 & .108 & .341 & 2.239 & .034 & .846 & 1.182 \\
\hline X4 & .246 & .113 & .340 & 2.176 & .039 & .803 & 1.245 \\
\hline
\end{tabular}

Hasil perhitungan nilai tolerance menunjukan semua variabel bebas memiliki nilai tolerance lebih dari 0,10. Sementara itu, nilai Variance Inflation Factor (VIF) juga menunjukan semua variabel bebas memiliki nilai VIF $<10.00$. Sehingga pengujian ini dapat disimpulkan bahwa tidak terjadi multikolinearitas. 


\section{Uji Heteroskedastisitas}

\begin{tabular}{|c|c|c|c|c|c|c|c|}
\hline & & & $\begin{array}{l}\text { KUALITAS } \\
\text { SUMBER } \\
\text { DAYA } \\
\text { MANUSIA }\end{array}$ & $\begin{array}{c}\text { PEMANFAATAN } \\
\text { TEKNOLOGI } \\
\text { INFORMASI }\end{array}$ & $\begin{array}{l}\text { PENGAWASAN } \\
\text { KEUANGAN } \\
\text { PEMERINTAH } \\
\text { DAERAH }\end{array}$ & $\begin{array}{c}\text { SISTEM } \\
\text { PENGENDAL } \\
\text { IAN INTERN }\end{array}$ & $\begin{array}{l}\text { Unstandardize } \\
\text { d Residual }\end{array}$ \\
\hline \multirow{15}{*}{$\begin{array}{l}\text { Spear } \\
\text { man's } \\
\text { rho }\end{array}$} & KUALITAS & Correlation & 1.000 & $-.374^{*}$ & .135 & -.181 & .024 \\
\hline & $\begin{array}{l}\text { SUMBER } \\
\text { DAYA }\end{array}$ & $\begin{array}{l}\text { Coefficient } \\
\text { Sig. (2-tailed) }\end{array}$ & . & .042 & .475 & .339 & .898 \\
\hline & MANUSIA & $\mathrm{N}$ & 30 & 30 & 30 & 30 & 30 \\
\hline & PEMANFAAT & $\begin{array}{l}\text { Correlation } \\
\text { Coefficient }\end{array}$ & $-.374^{*}$ & 1.000 & -.080 & $.477^{* *}$ & -.127 \\
\hline & $\begin{array}{c}\text { AN } \\
\text { TEKNOLOGI }\end{array}$ & Sig. (2-tailed) & .042 & & .675 & .008 & .504 \\
\hline & INFORMASI & $\mathrm{N}$ & 30 & 30 & 30 & 30 & 30 \\
\hline & PENGAWASA & $\begin{array}{l}\text { Correlation } \\
\text { Coefficient }\end{array}$ & .135 & -.080 & 1.000 & -.106 & -.015 \\
\hline & KEUANGAN & Sig. (2-tailed) & .475 & .675 & & .579 & .939 \\
\hline & $\begin{array}{c}\text { PEMERINTA } \\
\text { H DAERAH }\end{array}$ & $\mathrm{N}$ & 30 & 30 & 30 & 30 & 30 \\
\hline & \multirow{3}{*}{$\begin{array}{c}\text { SISTEM } \\
\text { PENGENDALI } \\
\text { AN INTERN }\end{array}$} & $\begin{array}{l}\text { Correlation } \\
\text { Coefficient }\end{array}$ & -.181 & $.477^{* *}$ & -.106 & 1.000 & -.348 \\
\hline & & Sig. (2-tailed) & .339 & .008 & .579 & . & .060 \\
\hline & & $\mathrm{N}$ & 30 & 30 & 30 & 30 & 30 \\
\hline & \multirow{3}{*}{$\begin{array}{l}\text { Unstandardized } \\
\text { Residual }\end{array}$} & $\begin{array}{l}\text { Correlation } \\
\text { Coefficient }\end{array}$ & .024 & -.127 & -.015 & -.348 & 1.000 \\
\hline & & Sig. (2-tailed) & .898 & .504 & .939 & .060 & \\
\hline & & $\mathrm{N}$ & 30 & 30 & 30 & 30 & 30 \\
\hline
\end{tabular}

Berdasarkan output pada Tabel 4.13 di atas diketahui bahwa nilai signifikan variabel kualitas sumber daya manusia (X1) sebesar 0,884, variabel pemanfaatan teknologi informasi (X2) sebesar 0,488, untuk variabel pengawasan keuangan daerah sebesar 0,594, dan untuk variabel sistem pengendalian intern (X4) sebesar 0,009. Jadi dapat disimpulkan bahwa nilai signifikansi pada variabel X1, X2 dan X3 lebih besar dari 0,05 yang artinya tidak terjadinya Heteroskedastisitas. Sementara itu nilai signifian pada variabel X4 lebih kecil dari 0,05 yang artinya terjadinya Heteroskedastisitas. 


\subsubsection{Pengujian Hipotesis}

\section{Uji-t (uji parsial)}

\begin{tabular}{|c|c|c|c|c|c|c|c|c|}
\hline \multirow{2}{*}{\multicolumn{2}{|c|}{ Model }} & \multicolumn{2}{|c|}{$\begin{array}{l}\text { Unstandardized } \\
\text { Coefficients }\end{array}$} & \multirow{2}{*}{$\begin{array}{c}\begin{array}{c}\text { Standardized } \\
\text { Coefficients }\end{array} \\
\text { Beta }\end{array}$} & \multirow[t]{2}{*}{$\mathrm{t}$} & \multirow[t]{2}{*}{ Sig. } & \multicolumn{2}{|c|}{ Collinearity Statistics } \\
\hline & & B & Std. Error & & & & Tolerance & VIF \\
\hline \multirow[t]{5}{*}{1} & (Constant) & -4.590 & 4.899 & & -.937 & .358 & & \\
\hline & $\begin{array}{c}\text { KUALITAS SUMBER } \\
\text { DAYA MANUSIA }\end{array}$ & .156 & .100 & .232 & 1.554 & .133 & .882 & 1.133 \\
\hline & $\begin{array}{c}\text { PEMANFAATAN } \\
\text { TEKNOLOGI } \\
\text { INFROMASI }\end{array}$ & .134 & .070 & .302 & 1.930 & .065 & .802 & 1.247 \\
\hline & $\begin{array}{c}\text { PENGAWASAN } \\
\text { KEUANGAN } \\
\text { DAERAH }\end{array}$ & .243 & .108 & .341 & 2.239 & .034 & .846 & 1.182 \\
\hline & $\begin{array}{c}\text { SISTEM } \\
\text { PENGENDALIAN } \\
\text { INTERN }\end{array}$ & .246 & .113 & .340 & 2.176 & .039 & .803 & 1.245 \\
\hline
\end{tabular}

- Nilai thitung untuk kualitas sumber daya manusia $(1,554)$ lebih kecil dibandingkan dengan nilai $\mathrm{t}_{\text {tabel }}(1,708)$ atau nilai sig. $(0,133)$ lebih besar dari alpha $(0,05)$. Berdasarkan hasil yang diperoleh maka menerima $\mathrm{H}_{0}$ dan menolak $\mathrm{H}_{\mathrm{a}}$. Hasil penelitian ini menunjukan bahwa kualitas sumber daya manusia tidak berpengaruh signifikan terhadap ketepatwaktuan pelaporan keuangan di BPK-AD Kantor Walikota Manado.

- Nilai $t_{\text {hitung }}$ untuk pemanfaatan teknologi informasi $(1,930)$ lebih besar dibandingkan dengan nilai $t_{\text {tabel }}(1,708)$ atau nilai sig. pemanfaatan teknologi informasi $(0,065)$ lebih besar dari alpha $(0,05)$. Berdasarkan hasil yang diperoleh maka menerima $\mathrm{H}_{0}$ dan menolak $\mathrm{H}_{\mathrm{a}}$. Hasil penelitian ini menunjukan bahwa pemanfaatan teknologi informasi tidak berpengaruh signifikan terhadap ketepatwaktuan pelaporan keuangan di BPK-AD Kantor Walikota Manado.

- Nilai $t_{\text {hitung }}$ untuk pengawasan keuangan daerah $(2,239)$ lebih besar dibandingkan dengan nilai $t_{\text {tabel }}(1,708)$ atau nilai sig. pengawasan keuangan daerah $(0,034)$ lebih kecil dari alpha $(0,05)$. Berdasarkan hasil yang diperoleh maka menolak $\mathrm{H}_{0}$ dan menerima $\mathrm{H}_{\mathrm{a}}$. Hasil penelitian ini menunjukan bahwa pengawasan keuangan daerah berpengaruh signifikan terhadap ketepatwaktuan pelaporan keuangan di BPK-AD Kantor Walikota Manado.

- Nilai $t_{\text {hitung }}$ untuk sistem pengendalian intern $(2,176)$ lebih besar dibandingkan dengan nilai $t_{\text {tabel }}(1,708)$ atau nilai sig. sistem pengendalian intern $(0.039)$ lebih kecil dari alpha $(0,05)$. Berdasarkan hasil yang diperoleh maka menolak $\mathrm{H}_{0}$ dan menerima $\mathrm{H}_{\mathrm{a}}$. Hasil penelitian ini menunjukan bahwa sistem pengendalian intern tidak berpengaruh signifikan terhadap ketepatwaktuan pelaporan keuangan pemerintah daerah di BPK-AD Kantor Walikota Manado.

2. Uji F (uji simultan)

\begin{tabular}{|c|c|c|c|c|c|c|}
\hline \multicolumn{2}{|r|}{ Model } & $\begin{array}{l}\text { Sum of } \\
\text { Squares }\end{array}$ & Df & $\begin{array}{l}\text { Mean } \\
\text { Square }\end{array}$ & $\mathrm{F}$ & Sig. \\
\hline \multirow{3}{*}{1} & Regression & 16.717 & 4 & \multirow{3}{*}{$\begin{array}{r}4.179 \\
.643\end{array}$} & \multirow[t]{3}{*}{6.496} & \multirow[t]{3}{*}{$.001^{\mathrm{b}}$} \\
\hline & Residual & 16.083 & 25 & & & \\
\hline & Total & 32.800 & 29 & & & \\
\hline
\end{tabular}

Pada Tabel 4.15 diketahui hasil $\mathrm{F}_{\text {hitung }}$ adalah sebesar 6,496. Besarnya nilai $F_{\text {tabel }}$ pada $\mathrm{df}_{1}($ jumlah variabel -1$)=4$ dan $\mathrm{df}_{2}(\mathrm{n}-\mathrm{k}-1)$ atau 30-6-1 $=23$ 
maka diperoleh $\mathrm{F}_{\text {tabel }}$ pada $\alpha=0,05$ sebesar 2,80. Hasil penelitian menunjukan $\mathrm{F}_{\text {hitung }}>\mathrm{F}_{\text {tabel }} \mathrm{H}_{\mathrm{a}}$ diterima.

Dengan demikian hasil uji $\mathrm{F}$ menyatakan $\mathrm{H}_{\mathrm{a}}$ diterima, artinya kualitas sumber daya manusia, pemanfaatan teknologi informasi, pengawasan keuangan daerah dan sistem pengendalian intern secara bersama-sama (simultan) memiliki pengaruh yang signifikan terhadap ketepatwaktuan pelaporan keuangan pemerintah daerah dengan nilai $F_{\text {hitung }}>F_{\text {tabel }}(6,496>$ $2,80)$.

3. Koefisien Determinasi $\left(\mathbf{R}^{2}\right)$

\begin{tabular}{|c|r|r|r|r|}
\hline $\begin{array}{c}\text { Mode } \\
1\end{array}$ & R & R Square & $\begin{array}{c}\text { Adjusted R } \\
\text { Square }\end{array}$ & $\begin{array}{c}\text { Std. Error of } \\
\text { the Estimate }\end{array}$ \\
\hline 1 & $.714^{\mathrm{a}}$ & .510 & .431 & .802 \\
\hline
\end{tabular}

Berdasarkan Tabel 4.16 diatas diperoleh nilai koefisien $\mathrm{R}^{2}$ sebesar 0,510 atau $(51,3 \%)$. Hal ini menunjukan bahwa presentase sambungan pengaruh variabel independen (kualitas sumber daya manusia, pemanfaatan teknologi informasi, pengawasan keuangan daerah, sistem pengendalian intern) terhadap variabel dependen (ketepatwaktuan pelaporan keuangan pemerintah) mampu menjelaskan sebesar $(51,3 \%)$ variasi variabel dependen (ketepatwaktuan pelaporan keuangan pemerintah). Sedangkan sisanya sebesar $(48,7 \%)$ dipengaruhi atau dijelaskan oleh variabel lain yang tidak dimasukkan dalam model penelitian ini.

\subsection{Pembahasan}

\subsubsection{Pengaruh Kualitas Sumber Daya Manusia Terhadap Ketepatwaktuan Pelaporan Keuangan}

Berdasarkan hasil uji hipotesis secara parsial didapatkan bahwa kualitas sumber daya manusia tidak berpengaruh signifikan terhadap ketepatwaktuan pelaporan keuangan. Hal ini ditunjukan dari hasil pengujian dimana tingkat signifikan sebesar $0,133>0,05$. Hasil penelitian ini sejalan dengan penelitian yang dilakukan oleh Lismawati (2012) yang menghasilkan kualitas sumber daya manusia tidak berpengaruh signifikan terhadap ketepatwaktuan pelaporan keuangan.

Ketidaksignifikanan ini mungkin disebabkan kondisi kualitas sumber daya manusia di subbagian akuntansi atau tata usaha keuangan yang belum mendukung baik dari segi kualitas maupun kuantitas. Dari sisi kualifikasi, masih ada pegawai subbagian akuntansi/tata usaha keuangan tidak memiliki latar belakang pendidikan akuntansi dan hal ini terlihat dari data demografi responden. Dari sisi kuantitas, masih sangat sedikit jumlah akuntan atau pegawai yang berpendidikan tinggi akuntansi, sementara peraturan perundang-undangan telah mewajibkan setiap satuan kerja untuk menyelenggarakan akuntansi dan menyusun laporan keuangan, maka pegawai yang ada yang diberdayakan. Kelemahan yang ada diimbangi dengan mengikutsertakan pegawai dalam pelatihan-pelatihan yang berhubungan dengan akuntansi dan pengelolaan keuangan daerah seperti pelatihan bendahara, pelatihan SIMDA keuangan, dan pelatihan penatausahaan pengelolaan keuangan daerah. Akan tetapi, hasil penelitian ini tidak sejalan dengan Sinarwati (2014) menghasilkan kualitas sumber daya manusia berpengaruh positif signifikan terhadap ketepat waktuaan pelaporan keuangan.

\subsubsection{Pengaruh Pemanfaatan Teknologi Informasi Terhadap Ketepatwaktuan Pelaporan Keuangan}

Berdasarkan hasil uji hipotesis secara parsial didapatkan bahwa pemanfaatan teknologi informasi tidak berpengaruh signifikan terhadap ketepatwaktuan pelaporan 
keuangan. Hal ini ditunjukan dari hasil pengujian dimana tingkat signifikan sebesar $0,065>0,05$. Akan tetapi, hasil penelitian ini tidak sejalan dengan Pujiswara (2014), Sinarwati (2014) dan Trisaputra (2013) yang menyimpulkan bahwa pemanfaatan teknologi informasi berpengaruh signifikan terhadap ketepat waktuan pelaporan keuangan. Pemanfaatan teknologi informasi yang meliputi teknologi komputer, internet dan teknologi komunikasi dalam pengelolaan keuangan daerah akan meningkatkan pemrosesan transaksi dan data lainnya, keakurasian dalam perhitungan, serta penyiapan laporan dan output lainnya lebih tepat waktu.

\subsubsection{Pengaruh Pengawasan Keuangan Daerah Terhadap Ketepatwaktuan Pelaporan Keuangan}

Berdasarkan hasil uji hipotesis secara parsial didapatkan bahwa sistem pengendalian intern berpengaruh signifikan terhadap ketepat waktuan pelaporan keuangan. Hal ini ditunjukan dari hasil pengujian dimana tingkat signifikan sebesar $0,034<0,05$. Hasil penelitian ini sejalan dengan penelitian yang dilakukan oleh Bagia, $d k k$ (2014), Pujiswara (2014), Sinarwati (2014) dan Trisaputra (2013) yang menghasilkan pengawasan keuangan daerah signifikan terhadap ketepatwaktuan pelaporan keuangan.

\subsubsection{Pengaruh Sistem Pengendalian Intern Terhadap Ketepatwaktuan Pelaporan Keuangan}

Berdasarkan hasil uji hipotesis secara parsial didapatkan bahwa pengawasan keungan daerah terhadap ketepatwaktuan pelaporan keuangan berpengaruh signifikan terhadap ketepatwaktuaan pelaporan keuangan. Hal ini ditunjukan dari hasil pengujian dimana tingkat signifikan sebesar $0,039<0,05$. Hasil penelitian ini sejalan dengan penelitian yang dilakukan oleh Bagia, $d k k$ (2014) dan Sinarwati (2014) yang menghasilkan sistem pengendalian intern signifikan terhadap ketepatwaktuan pelaporan keuangan.

\section{KESIMPULAN DAN SARAN}

5.1. Kesimpulan

Hasil penelitian dan pembahasan di atas, maka dapat ditarik kesimpulan sebagai berikut:

1. Kualitas sumber daya manusia tidak bepengaruh secara signifikan terhadap ketepatwaktuan pelaporan keuangan di BPK-AD Kantor Walikota Manado.

2. Pemanfaatan teknologi informasi tidak bepengaruh secara signifikan terhadap ketepatwaktuan pelaporan keuangan di BPK-AD Kantor Walikota Manado.

3. Pengawasan keuangan daerah bepengaruh signifikan terhadap ketepatwaktuan pelaporan keuangan di BPK-AD Kantor Walikota Manado.

4. Sistem pengendalian intern bepengaruh signifikan terhadap ketepatwaktuan pelaporan keuangan di BPK-AD Kantor Walikota Manado.

\subsection{Saran}

Berdasarkan hasil penelitian dan pembahasan di atas, maka penulis memberi saran sebagai berikut :

1. Agar ketepatwaktuan pelaporan keuangan daerah dapat berjalan dengan baik, sebaiknya perlu adanya peningkatan sumber daya manusia, pemanfaatan teknologi informasi, pengawasan keuangan daerah dan sistem pengendalian intern. Dengan peningkatan dan perbaikan tersebut akan mampu mengurangi adanya ketidak sesuaian penyajian laporan keuangan yang tidak memenuhi Standar Akuntansi Pemerintah.

2. Bagi peneliti berikutnya supaya dapat memfokuskan sampel penelitian. Karena penelitian ini hanya memfokuskan di BPK-AD Kantor Walikota Manado. 
Sehingga bagi peneliti berikutnya sebaiknya memperluas dan mengambil sampel di pemerintahan daerah lain.

3. Bagi peneliti selanjutnya supaya dapat mempertimbangkan untuk menambahkan variabel-variabel lain yang diduga berpengaruh terhadap ketepatwaktuan dan keterandalan pelaporan keuangan pemerintah daerah, misalnya komitmen organisasi dan gaya kepemimpinan.

\section{DAFTAR PUSTAKA}

Abdul, Halim. 2012. Akuntansi Sektor Publik, Akuntansi Keuangan Daerah. Edisi 4. Salemba Empat.

Alifah, Syayyudah. 2014. "Faktor-faktor Yang Mempengaruhi Nilai Informasi Pelaporan Keuangan Badan Layanan Umum (Studi pada PK BLU Universitas Negeri Surabaya)”. Sekolah Tinggi Ilmu Ekonomi Indonesia (STIESIA) Surabaya.

Annisa, dkk. 2014. "Financial and Performance Transparancy on The Local Government Websites in Indonesia". Department of Accounting, Faculty of Economics, Universitas Indonesia.

Argo, Trihapsoro. 2015. "Pengaruh Kualitas Sumber Daya Manusia, Pemanfaatan Teknologi Informasi Dan Sistem Pengendalian Intern Pemerintah Terhadap Kinerja Pemerintah Daerah”. Fakultas Ekonomi Dan Bisinis, Universitas Muhammadiyah Surabaya.

Astuti, dkk. 2014. "Sistem Pengendalian Intern Dan Kualitas Laporan Keuangan Pemerintah Daerah Di Indonesia”. Fakultas Ekonomi Universitas Slamet Riyadi Surakarta.

Bagia, dkk. 2014. "Pengaruh Sistem Pengendalian Intern Pemerintah dan Pengawasan

Keuangan Daerah Terhadap Nilai Informasi Laporan keuangan Pemerintah Pada Satuan Kerja Perangkat Daerah (SKPD)”. Jurusan Manajemen Universitas Pendidikan Ganesha Singaraja, Indonesia.

Deddy, dkk. 2012. Akuntansi Pemerintahan. Cetakan Ketiga. Salemba Empat. Jakarta.

Husna, Fadhilla. 2013. "Pengaruh Kualitas Sumber Daya Manusia, Pengawasan Keuangan,

Dan Sistem Pengendalian Intern Pemerintah Terhadap Nilai Pelaporan Keuangan Pemerintah (Studi Empiris Pada Skpd Pemerintah Kota Padang Panjang)". Program Studi Akuntansi, Fakultas Ekonomi, Universitas Padang.

Ikhtisar Hasil Pemeriksaan Semester I Tahun 2015.

Kuncoro, Mudrajad. 2013. Metode Riset Untuk Bisnis \& Ekonomi. Edisi 2.

Lismawati, 2012. "Pengaruh Kemampuan Sumber Daya Manusia Terhadap Keterandalan Dan Keteptaktuan Pelaporan Keuangan Pemerintah Daerah”. Fakultas Ekonomi Dan Bisnis, Universitas Muhammadiyah Surabaya. Surabaya.

Marshall B. Romney, Paul John Steinbart. 2014. Sistem Informasi Akuntansi: Accounting Information Systems. Edisi 13. Salemba Empat.

Pituringsih, dkk. 2015. "Pengaruh Kualitas Sumber Daya Manusia, Pemanfaatan Teknologi Informasi, Pengendalian Intern Akuntansi,Dan Pengawasan Keuangan Daerah Terhadap Keandalan Laporan Keuangan Daerah Pada SKPD Pemerintah Kabupaten Lombok Timur”. Fakultas Akuntansi Universitas Mataram.

Pujiyanti, Ferra. 2015. Akuntansi Dasar Penerbit: Lembar Pustaka Indonesia. Tangerang. 
Pujiswara, dkk. 2014. "Pengaruh Pemanfaatan Sistem Informasi Akuntansi Keuangan Daerah Dan Pengawasan Keuangan Daerah Terhadap Nilai Informasi Pelaporan Keuangan Dan Akuntabilitas Pemerintah Daerah (Studi pada Satuan Kerja Perangkat Daerah di Kabupaten Klungkung)”. Fakultas Ekonomi, Universitas Pendidikan Ganesha.

Ramadhanti, dkk. 2016. " The Effect of Used Information Technology, Internal Control, and Regional Accounting System on the Performance of City Governance Agency of Banda Aceh City, Indonesia “. Dept of Accounting, Faculty of Economics and Business University of Syiah Kuala, Banda Aceh, Indonesia.

Sembiring, Febriady. 2013. "Pengaruh Kualitas Sumber Daya Manusia, Pemanfaatan Teknologi Informasi Dan Sistem Pengendalian Intern Terhadap Keandalan Dan Ketapatwaktuan Pelaporan Keuangan Pemerintah”. Fakultas Ekonomi, Universitas Negeri Padang.

Sinarwati, dkk. 2014. "Pengaruh Kualitas Sdm, Pemanfaatan Ti, Dan Sistem Pengendalian Intern Terhadap Nilai Informasi Pelaporan Keuangan Pemerintah Daerah”. Jurusan Akuntansi, Universitas Pendidikan Ganesha Singaraja, Indonesia.

Sinarwati, dkk. 2015. "Faktor-faktor Yang Mempengaruhi Keterandalan Nilai Informasi Pelaporan Keuangan Pemerintah Daerah (Studi pada SKPD Kabupaten Jembrana). Jurusan Akuntansi, Universitas Pendidikan Ganesha Singaraja, Indonesia.

Suwanda, Dadang. 2015. “ Factors Affecting Quality of Local Government Financial Statements to Get Unqualified Opinion (WTP) of Audit Board of the Republic of Indonesia (BPK) “. Faculty of Economics and Business, University of Padjajaran Bandung.

Trisaputra, Andry. 2013. "Pengaruh Pemanfaatan Teknologi Informasi Dan Pengawasan Keuangan Daerah Terhadap Ketepatwaktuan Pelaporan Keuangan Pemerintah Daerah (Studi Empiris Pada Skpd Pemerintah Provinsi Sumatera Barat). Program Studi Akuntansi Fakultas Ekonomi Universitas Negeri Padang.

Wiboyo, Agung Edy. 2012. Aplikasi Praktis SPSS Dalam Penelitian. Gava Media. Yogyakarta.

Zuliarti, 2012. "Pengaruh Kapasitas Sumber Daya Manusia,Pemanfaatan Teknologi Informasi, Dan Pengendalian Intern Akuntansi Terhadap Nilai Informasi Pelaporan Keuangan Pemerintah Daerah”. Fakultas Ekonomi Universitas Muria Kudus.

PP Nomor 24 Tahun 2005 tentang Standar Akuntansi Pemerintahan

PP Nomor 24 Tahun 2005 tentang Kerangka Konseptual Akuntansi Pemerintahan 